\title{
Delusional infestation in clinical practice over a period of two decades
}

\author{
Radomir Reszke, Przemysław Pacan², Adam Reich³, Jacek C. Szepietowski ${ }^{1}$ \\ ${ }^{1}$ Department of Dermatology, Venereology and Allergology, Wroclaw Medical University, Wroclaw, Poland \\ ${ }^{2}$ Department of Psychiatry, Wroclaw Medical University, Wroclaw, Poland \\ ${ }^{3}$ Department of Dermatology, University of Rzeszow, Rzeszow, Poland
}

Adv Dermatol Allergol 2021; XXXVIII (1): 144-150 DOI: https://doi.org/10.5114/ada.2019.88464

\begin{abstract}
Introduction: Patients presenting with cutaneous symptomatology may in fact suffer from underlying psychiatric conditions. Individuals diagnosed with delusional infestation (DI) have a fixed false belief of being infested with certain organisms or objects.

Aim: To analyse clinical features of subjects with DI who were admitted to the tertiary dermatology ward.

Material and methods: A retrospective analysis concerning DI patients hospitalized between 1997 and 2019 was carried out. The emphasis was put on the duration of symptoms, psychiatric symptomatology (including the "specimen sign"), comorbidities as well as therapy.

Results: We gathered data regarding 21 consecutive patients with DI. The mean age of subjects was $65.2 \pm 13.3$ years, the majority were females (76.2\%). The mean time span between the disease onset and diagnosis was 1.9 \pm 1.7 years. Previous psychiatric consultations were attended by $57.0 \%$ of patients. The specimen sign was present in $47.6 \%$ of cases, whereas the most common suspected causative factors were described as worms (52.4\%), unspecified parasites (42.9\%), "something" (33.3\%) and flies (19.0\%). Primary delusional disorder was diagnosed in 76.2\%, followed by shared delusional disorder and secondary delusional disorder of organic origin (9.5\% each). Risperidone monotherapy was initiated in $61.9 \%$ of patients. In total, only $33.3 \%$ of patients attended the follow-up visit.

Conclusions: DI features a wide spectrum of clinical signs and symptoms. Risperidone remains the drug of choice in the majority of cases. Successful management of each DI case requires collaboration between dermatologists and psychiatrists and still remains a major challenge.
\end{abstract}

Key words: delusional parasitosis, Ekbom's syndrome, psychodermatology, risperidone.

\section{Introduction}

Psychodermatology is a relatively new field of medicine created from merging dermatology and psychiatry which explores complex interactions between the mind and the skin [1]. Occasionally, patients presenting to dermatologists may complain of symptoms primarily of psychiatric origin. Such is the case with individuals suffering from delusional infestation (DI) who have a false belief that their skin and body are infested by small vivid pathogens or inanimate objects [2]. DI has many synonyms in the literature, firstly described as acarophobie by Thibierge (1894), and was subsequently termed präseniler dermatozonewahn, delusions of parasitosis or Ekbom's syndrome [3]. The annual incidence rate of DI was estimated as 16.6 cases per million inhabitants, with a prevalence of 83.21 cases per million. Women are approximately 2.5 times more often affected than men, although this observation concerns women aged 45 years and older suffering from primary DI [2]. Primary DI cannot be explained by other conditions and is a synonym of persistent delusional disorder (F22.0 according to the ICD-10 classification) or shared DI (induced psychotic disorder F24.0), whereas secondary DI occurs due to various conditions such as depression, schizophrenia, dementia, stroke, diabetes, HIV infection, medical drugs intake (e.g. ciprofloxacin), drug abuse (cocaine) or vitamin deficiencies [4-11], to mention just a few. The bizarre nature of DI is supported by the "specimen sign" (formerly described as the "matchbox sign" in 1983) [12]. It is considered

Address for correspondence: Prof. Jacek C. Szepietowski, Department of Dermatology, Venereology and Allergology, Wrocław Medical University, 1 Chalubinskiego St, 50-368 Wroclaw, Poland, e-mail: jacek.szepietowski@umed.wroc.pl Received: 31.07.2019, accepted: 13.08.2019. 
a classic feature of DI and denotes samples of suspected parasites or other factors being brought for analysis by the patients. "Specimen sign" is a more appropriate term than "matchbox sign" as it focuses on any kind of samples being brought for examination, not the receptacle [2]. Due to its rarity, to date, most data on DI have come from case reports or small cases series.

\section{Aim}

This study aimed to analyse clinical features of a group of 21 subjects with DI who were admitted to a tertiary dermatology ward in order to aid clinicians in successfully performing their diagnostic and therapeutic procedures in this challenging group of patients.

\section{Material and methods}

A retrospective descriptive analysis of DI patients hospitalized between 1997 and 2019 in the dermatology department was carried out based on the available doc- umentation. The diagnosis of DI was established upon typical clinical features and psychiatric consultation. The emphasis was put on the duration of symptoms, psychiatric symptomatology (including the presence of the specimen sign), systemic comorbidities, follow-up visit attendance as well as the initiated treatment and associated outcome.

\section{Results}

The data regarding 21 consecutive patients were obtained. The mean age of subjects was $65.2 \pm 13.3$ years (range: $39-89$ years), with the majority being females $(n=16 ; 76.2 \%)$. Regarding marital status, 9 were married (42.8\%), 6 were widowed (28.6\%), 3 were single and 3 were divorced (14.3\% each). The majority of subjects $(n=15 ; 71.4 \%)$ reported living with at least one family member, 6 lived alone (28.6\%). Fifty-seven percent of patients $(n=12)$ reported that they had visited a psychiatrist at least once before current admission. Among those, depression, anxiety disorder, alcohol dependence,
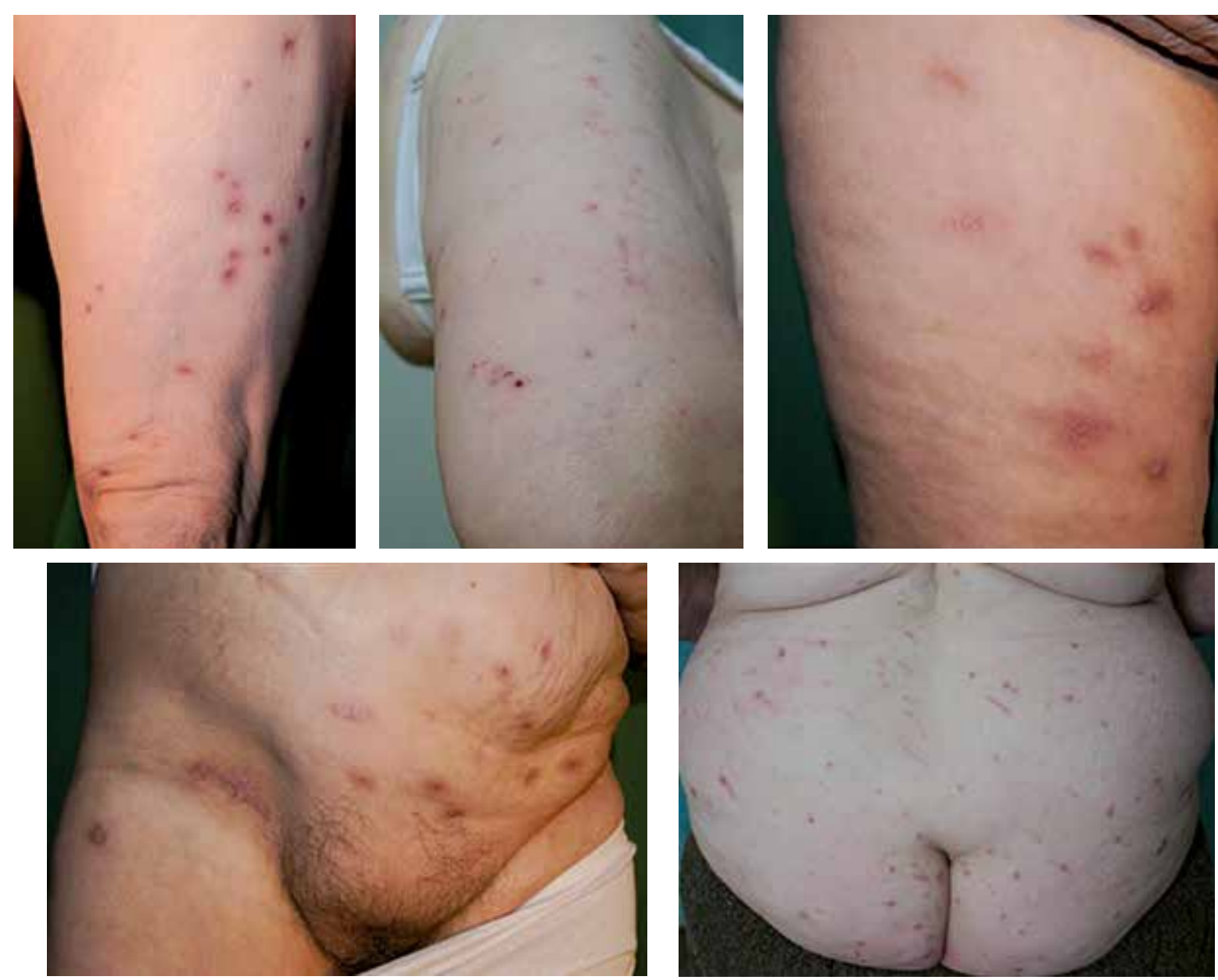

Figure 1. Photographs of the clinical lesions in DI patients 
benzodiazepine dependence and adaptive reaction had bothered one subject each. Coexisting comorbidities encompassed arterial hypertension ( $n=6 ; 28.6 \%$ ), mild anaemia ( $n=3 ; 14.3 \%)$, hypothyreosis, type II diabetes and implanted cardiac defibrillator due to arrhythmia ( $n=2 ; 9.5 \%$ each), rheumatoid arthritis, atopic dermatitis and psoriasis ( $n=1 ; 4.8 \%$ each). Before being referred to the dermatology ward, 8 (38.1\%) patients were treated for suspected scabies infestation with permethrin or crotamiton. The mean duration of symptoms prior to admission was $1.9 \pm 1.7$ years (range: 1 month -5 years). All patients presented with a variety of skin lesions attributed to chronic scratching or attempts to remove the imaginary parasites (erythema, erosions, excoriations, crusts, hyperpigmentation, scars), usually located on the trunk and lower limbs (Figure 1). The specimen sign was present in $47.6 \%$ of cases $(n=10)$, usually consisting of dirt, sand, threads or debris presented in a plastic container (Figure 2). Among those, 3 patients also drew the images of the suspected causative factors on a piece of paper. Patients provided abundant verbal descriptions of suspected causative factors of their symptoms (Table 1$)$, with worms ( $n=11 ; 52.4 \%)$, unspecified parasites $(n=9$; $42.9 \%)$, "something" $(n=7 ; 33.3 \%)$ and flies $(n=4$; $19 \%$ ) reported most commonly. The need of a psychiatric consultation by a dedicated psychiatrist was explained to all patients and each agreed to participate. Overall, a psychiatric consultation was performed in 20 (95.2\%) patients (1 patient left the ward without informing medi-
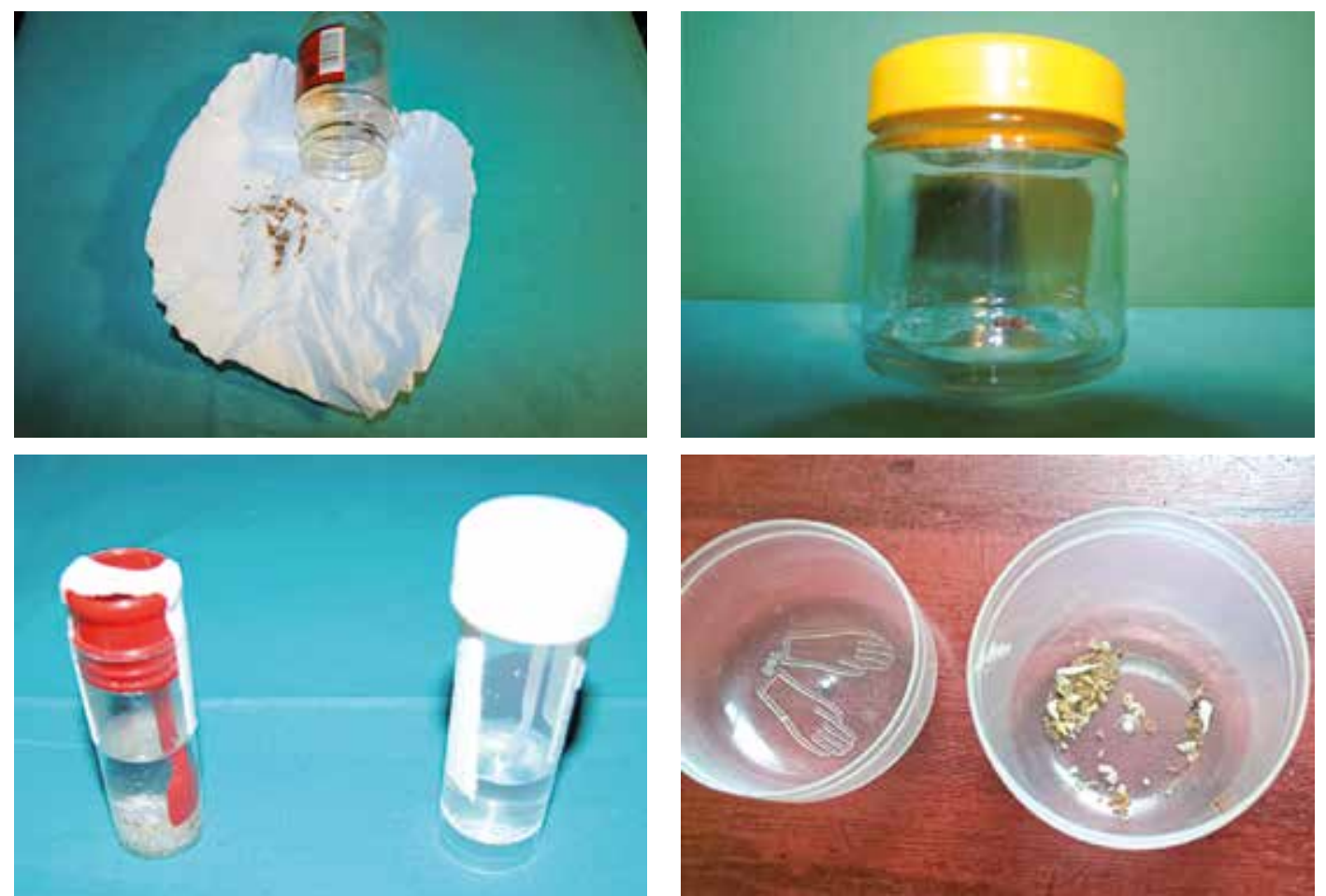

Figure 2. The specimen sign cal personnel of his intentions before being consulted). Primary delusional disorder was diagnosed in 16 (76.2\%) patients (F22.0), followed by shared delusional disorder (F24) and secondary delusional disorder of organic origin (2 patients each; 9.5\%) (F06.2). Regarding the diagnosis of shared delusional disorder (folie a deux), 2 patients (a 79-year-old male and a 66-year-old female) were a married couple. The belief of infestation had started 5 years earlier in the woman. They expressed that the "worms" appeared because of the homeless person who periodically resided in the garden shed. The couple consulted dermatologists, parasitologists, veterinarians and entomologists. They applied household detergents to their skin which resulted in skin irritation. A disinfection of the apartment was performed thrice; the furniture was also removed.

Risperidone was initiated in $61.9 \%$ of patients $(n=13)$, usually starting with $0.5-2 \mathrm{mg}$ nightly, with a gradual dose increase. Among patients treated with risperidone, haloperidol monotherapy preceded treatment with risperidone in 1 patient, whereas unsuccessful olanzapine course was followed by instigating risperidone in the other patient. Other treatment modalities included perazine, promazine, haloperidol (in monotherapy or in combination with paroxetine) and chlorprothixene. Two (9.5\%) patients refused to initiate treatment with risperidone. Unfortunately, only 7 patients (33.3\% in total) attended the follow-up visit, whereas a partial remission of symptoms was observed in 5 of them (23.8\% in total).

Figure 2. The specimen sign 
Table 1. The data regarding clinical characteristics of DI patients

\begin{tabular}{|c|c|c|c|c|c|c|c|c|c|}
\hline $\begin{array}{l}\text { Patient } \\
\text { no. }\end{array}$ & Age & Sex & $\begin{array}{c}\text { Marital and family } \\
\text { status }\end{array}$ & $\begin{array}{l}\text { Duration of } \\
\text { symptoms }\end{array}$ & $\begin{array}{l}\text { Specimen } \\
\text { sign }\end{array}$ & $\begin{array}{c}\text { Previous } \\
\text { psychiatric } \\
\text { consultations }\end{array}$ & $\begin{array}{l}\text { Treatment } \\
\text { (final dose) }\end{array}$ & $\begin{array}{l}\text { Follow- } \\
\text { up }\end{array}$ & Outcomes \\
\hline 1 & 41 & $\mathrm{~F}$ & $\begin{array}{l}\text { Married, children, } \\
\text { lives with the } \\
\text { family }\end{array}$ & 3 years & No & Yes & $\begin{array}{c}\text { Perazine } \\
(100 \mathrm{mg} / \text { day })\end{array}$ & Yes & Partial remission \\
\hline 2 & 39 & M & $\begin{array}{l}\text { Bachelor, no } \\
\text { children, lives } \\
\text { alone }\end{array}$ & 6 months & No & No & $\begin{array}{l}\text { Risperidone } \\
\text { (5 mg/day) }\end{array}$ & No & \\
\hline 3 & 55 & $\mathrm{~F}$ & $\begin{array}{l}\text { Married, children, } \\
\text { lives with the } \\
\text { family }\end{array}$ & 3 months & No & Yes & $\begin{array}{l}\text { Risperidone } \\
\text { (3 mg/day) }\end{array}$ & No & \\
\hline $4^{*}$ & 79 & M & $\begin{array}{l}\text { Married, children, } \\
\text { lives with the } \\
\text { family }\end{array}$ & 7 months & Yes & No & $\begin{array}{l}\text { Risperidone } \\
\text { (2 mg/day) }\end{array}$ & No & \\
\hline $5^{\star}$ & 66 & $\mathrm{~F}$ & $\begin{array}{l}\text { Married, children, } \\
\text { lives with the } \\
\text { family }\end{array}$ & 5 years & Yes & Yes & $\begin{array}{l}\text { Risperidone } \\
\text { (2 mg/day) }\end{array}$ & No & \\
\hline 6 & 66 & $\mathrm{~F}$ & $\begin{array}{l}\text { Married, children, } \\
\text { lives with the } \\
\text { family }\end{array}$ & 5 months & Yes & No & $\begin{array}{l}\text { Risperidone } \\
\text { (2 mg/day) }\end{array}$ & Yes & Partial remission \\
\hline 7 & 64 & $\mathrm{~F}$ & $\begin{array}{l}\text { Widow, children, } \\
\text { lives with the } \\
\text { family }\end{array}$ & 1 year & No & Yes & $\begin{array}{l}\text { Haloperidol ( } 2.5 \\
\text { mg/day) followed } \\
\text { by risperidone } \\
\text { ( } 2 \mathrm{mg} / \text { day })\end{array}$ & No & \\
\hline 8 & 68 & $\mathrm{~F}$ & $\begin{array}{l}\text { Divorced, children, } \\
\text { lives alone }\end{array}$ & 1 year & No & Yes & $\begin{array}{l}\text { Haloperidol } \\
(2.5 \mathrm{mg} / \text { day })\end{array}$ & No & \\
\hline 9 & 52 & $\mathrm{~F}$ & $\begin{array}{l}\text { Widow, children, } \\
\text { lives with the } \\
\text { family }\end{array}$ & 3 years & No & Yes & $\begin{array}{l}\text { Paroxetine } \\
(20 \mathrm{mg} / \mathrm{d}) \\
\text { Haloperidol } \\
(3 \mathrm{mg} / \mathrm{d})\end{array}$ & Yes & Partial remission \\
\hline 10 & 79 & $\mathrm{~F}$ & $\begin{array}{l}\text { Married, children, } \\
\text { lives with the } \\
\text { family }\end{array}$ & 2 years & Yes & Yes & $\begin{array}{l}\text { Risperidone } \\
\text { (6 mg/day) }\end{array}$ & Yes & $\begin{array}{l}\text { No remission, } \\
\text { discontinued } \\
\text { treatment }\end{array}$ \\
\hline 11 & 62 & $\mathrm{~F}$ & $\begin{array}{l}\text { Widow, children, } \\
\text { lives alone }\end{array}$ & 2 months & Yes & No & $\begin{array}{l}\text { Refused } \\
\text { treatment with } \\
\text { risperidone }\end{array}$ & No & \\
\hline 12 & 89 & $\mathrm{~F}$ & $\begin{array}{l}\text { Widow, children, } \\
\text { lives with the } \\
\text { family }\end{array}$ & 1 month & No & No & $\begin{array}{l}\text { Promazine } \\
\text { (75 mg/day) }\end{array}$ & No & \\
\hline 13 & 62 & $\mathrm{~F}$ & $\begin{array}{l}\text { Single, children, } \\
\text { lives alone }\end{array}$ & 4 years & Yes & Yes & $\begin{array}{l}\text { Risperidone } \\
(2 \mathrm{mg} / \mathrm{d})\end{array}$ & Yes & $\begin{array}{l}\text { No remission, } \\
\text { discontinued } \\
\text { treatment due to } \\
\text { adverse effects }\end{array}$ \\
\hline 14 & 89 & $\mathrm{~F}$ & $\begin{array}{l}\text { Widow, children, } \\
\text { lives alone }\end{array}$ & 1 year & No & No & $\begin{array}{l}\text { Risperidone } \\
\text { (1 mg/day) }\end{array}$ & No & \\
\hline 15 & 58 & $\mathrm{~F}$ & $\begin{array}{l}\text { Single, children, } \\
\text { lives with the } \\
\text { family }\end{array}$ & 1 year & No & Yes & $\begin{array}{l}\text { Chlorprothixene } \\
\text { (50 mg/day) }\end{array}$ & Yes & Partial remission \\
\hline 16 & 70 & $\mathrm{~F}$ & $\begin{array}{l}\text { Divorced, children, } \\
\text { lives with the } \\
\text { family }\end{array}$ & 3 years & Yes & No & $\begin{array}{l}\text { Risperidone } \\
\text { (1.5 mg/day) }\end{array}$ & No & \\
\hline 17 & 56 & $M$ & $\begin{array}{l}\text { Married, children, } \\
\text { lives with the } \\
\text { family }\end{array}$ & 5 years & No & Yes & $\begin{array}{l}\text { Olanzapine } \\
\text { (20 mg/day) } \\
\text { followed by } \\
\text { risperidone } \\
\text { ( } 8 \mathrm{mg} / \text { day) }\end{array}$ & Yes & Partial remission \\
\hline
\end{tabular}


Table 1. Cont.

\begin{tabular}{|c|c|c|c|c|c|c|c|c|c|}
\hline $\begin{array}{c}\text { Patient } \\
\text { no. }\end{array}$ & Age & Sex & $\begin{array}{l}\text { Marital and family } \\
\text { status }\end{array}$ & $\begin{array}{l}\text { Duration of } \\
\text { symptoms }\end{array}$ & $\begin{array}{l}\text { Specimen } \\
\text { sign }\end{array}$ & $\begin{array}{c}\text { Previous } \\
\text { psychiatric } \\
\text { consultations }\end{array}$ & $\begin{array}{l}\text { Treatment } \\
\text { (final dose) }\end{array}$ & $\begin{array}{l}\text { Follow- } \\
\text { up }\end{array}$ & Outcomes \\
\hline 18 & 86 & $M$ & $\begin{array}{l}\text { Widower, children, } \\
\text { lives alone }\end{array}$ & 3 years & No & No & $\begin{array}{l}\text { Risperidone } \\
(1 \mathrm{mg} / \text { day })\end{array}$ & No & \\
\hline 19 & 70 & $\mathrm{~F}$ & $\begin{array}{l}\text { Married, children, } \\
\text { lives with the } \\
\text { family }\end{array}$ & 6 months & Yes & Yes & $\begin{array}{l}\text { Risperidone } \\
1 \mathrm{mg} / \text { day }\end{array}$ & No & \\
\hline 20 & 61 & $M$ & $\begin{array}{l}\text { Divorced, children, } \\
\text { lives with the } \\
\text { family }\end{array}$ & 5 years & Yes & Yes & None $^{\star \star}$ & No & \\
\hline 21 & 58 & $F$ & $\begin{array}{l}\text { Married, children, } \\
\text { lives with the } \\
\text { family }\end{array}$ & 1 year & Yes & Yes & $\begin{array}{l}\text { Refused } \\
\text { treatment with } \\
\text { risperidone }\end{array}$ & No & \\
\hline
\end{tabular}

*The patients were a married couple. ${ }^{* *}$ The patient left the ward without being consulted by a psychiatrist. No treatment was instigated.

Table 2. Suspected causative factors as reported by the patients

\begin{tabular}{lc}
\hline Suspected causative factors & Number of patients (percentage) \\
\hline Worms & $11 / 21(52.4)$ \\
\hline Parasites & $9 / 21(42.9)$ \\
\hline Something & $7 / 21(33.3)$ \\
\hline Flies & $4 / 21(19)$ \\
\hline Spiders & $2 / 21(9.5)$ \\
\hline Dove ticks (Argas reflexus) & $2 / 21(9.5)$ \\
\hline Bacteria & $1 / 21(4.8)$ \\
\hline Nematodes & $1 / 21(4.8)$ \\
\hline Roundworms & $1 / 21(4.8)$ \\
\hline Ascaris spp. & $1 / 21(4.8)$ \\
\hline Demodex spp. & $1 / 21(4.8)$ \\
\hline Ticks & $1 / 21(4.8)$ \\
\hline Black dots & $1 / 21(4.8)$ \\
\hline
\end{tabular}

One patient decided to discontinue risperidone due to adverse events (dizziness, tachycardia), while the other one due to no improvement of the symptoms perceived.

The summary of clinical data regarding the subjects is presented in Table 2 .

\section{Discussion}

To the best of our knowledge, this is the first report on DI among Polish patients involving such a big series of patients. DI is typically considered as a rare condition; nevertheless, our previous study suggests that it is commonly encountered in dermatological practice [13]. Approximately $85 \%$ of 118 dermatologists responding to the survey reported that they had seen at least 1 patient with DI during their practice. Frequently, the phenome- non of "doctor hopping" occurs. Patients attend various dermatologists, tropical disease specialists, as well as entomologists and microbiologists [2]. As reported in the present study, general practitioners and dermatologists often initiate topical treatment with anti-scabietic drugs. Occasionally, such treatment is instigated together with antipsychotics in order to gain patient's trust. Usually, establishing the diagnosis does not pose any difficulties due to the characteristic clinical picture. The specimen sign mostly involves dirt particles, sand, debris, fragments of epidermis, hair or cloth threads stored in plastic jars or bags; drawings, photographs or videos may also be presented. It is a classical yet not mandatory sign of DI; its prevalence in our study (10 out of 21 patients; $47.6 \%)$ was similar to other reports [14, 15].

Treatment of $\mathrm{DI}$ is problematic as patients may refuse to take psychiatric drugs and do not attend the followup visits. To establish trustful rapport it is necessary to carefully examine the specimens brought by the patients [16]. This also includes dermoscopy [17]. Additionally, the physician might consider taking a biopsy if the patient expects it [18]. The latter solution is based on two conditions firmly explained to the patient: the biopsy site is chosen by the physician and the patient agrees to reconsider his/ her beliefs if the results of histological examination do not support the presence of parasites. Tactile hallucinations, paraesthesias and pruritus are frequently experienced by the patients, yet paradoxically they may be considered physician's "allies" as the instigation of "psychiatric" drugs relieves these bothersome symptoms. Thereby, the expectations of both the patient and the physician are met, despite critical differences in the views concerning aetiology of the symptoms. In extremely rare cases though, the symptoms in subjects initially diagnosed with DI would eventually turn out to be truly associated with parasites, e.g. with Limothrips cerealium (grain thrips) or Dryomyza formosa (intestinal myiasis) [19, 20]. 
Antipsychotics constitute the main therapeutic modality of DI, although in most cases it is difficult to convince patients to initiate such treatment. In our patients psychiatric consultation was performed in the presence of the dermatologist, which might have contributed to higher initial compliance to treatment. A lack of willingness to attend the psychiatric consultation and refusal to instigate or continue psychoactive medication stem from the lack of insight and criticism of the affected patients. These aspects are direct consequences of psychotic symptomatology, such as delusions and tactile sensations. A first-generation antipsychotic, pimozide (currently unavailable in Poland), has been studied in the literature featuring the largest number of DI patients so far $[14,21,22]$. The newer substances belonging to the second-generation (atypical) antipsychotics also act as dopamine receptor $\left(D_{2}\right)$ antagonists; however, their antagonism towards serotonin receptors (particularly the $5-\mathrm{HT}_{2 \mathrm{a}}$ ) is more pronounced. Therefore, they still exert a high antipsychotic effect whilst reducing the risk of adverse events, such as the extrapyramidal syndrome [23, 24]. Currently, risperidone is considered as the drug of choice in DI [25]. The starting dose is usually $0.5-2 \mathrm{mg}$ nightly, gradually increased to $4-8 \mathrm{mg} /$ day. Notably, risperidone doses utilized in DI are usually smaller than in schizophrenia. A Japanese case report demonstrated a significant increase in regional cerebral blood flows in the bilateral frontal and left temporoparietal regions, the right parietal operculum and the bilateral basal ganglia after initiating risperidone in a patient with DI [26]. Compared to first-generation antipsychotics, risperidone is associated with a higher risk of metabolic syndrome, hyperprolactinemia and postural hypotension [24]. Moreover, an association with cerebrovascular incidents has also been observed in several studies among the elderly [2729], although this association is less pronounced than in patients treated with haloperidol or chlorpromazine [30] and similar to those using olanzapine or quetiapine [31]. Nevertheless, this drug should not be used in patients who underwent a stroke recently. Other atypical antipsychotics mentioned in case reports encompass aripiprazole (3.75-15 mg/day), olanzapine (2.5-10 mg/day), paliperidone (3 mg/day), quetiapine ( $25-50 \mathrm{mg} /$ day), sertindole (4-12 mg/day) and ziprasidone (120 mg/day) [32-39]. Unfortunately, long-term treatment with antipsychotics lasting from months or years is often necessary to maintain remission as early discontinuation of the drug following the initial success causes recurrence of symptoms.

Early instigation of treatment is relevant as the patients' symptoms may intensify, resulting in a suicidal attempt and occasionally leading to death [40]. During the clinical interview DI patients often appear reluctant to cooperate and secretive while verbal and physical aggression towards medical personnel also occurs occasionally. Remarkably, there was a report of an elderly female with DI who attempted to shoot her doctor with a hunting gun (fortunately she missed) [41]. The paper also mentions a personal communication referencing an unpublished case of a female with DI who shot her physician after being suggested to visit a psychiatrist.

\section{Conclusions}

DI patients present mainly to dermatologists despite the psychiatric origins of the disease and feature a variety of bizarre clinical manifestations. Based on the literature and similarly to other delusional disorders, DI may be treated with antipsychotics, both first-generation and atypical. Currently, risperidone is considered the mainstay of treatment. Managing these patients remains a challenge and requires strict cooperation between dermatologists and psychiatrists.

\section{Conflict of interest}

The authors declare no conflict of interest.

\section{References}

1. Jafferany M, Franca K. Psychodermatology: basics concepts. Acta Derm Venereol 2016; 96: 35-7.

2. Freudenmann RW, Lepping P. Delusional infestation. Clin Microbiol Rev 2009; 22: 690-732.

3. Trabert W. 100 years of delusional parasitosis. Meta-analysis of 1,223 case reports. Psychopathology 1995; 28: 238-46.

4. Slaughter JR, Zanol K, Rezvani H, Flax J. Psychogenic parasitosis. A case series and literature review. Psychosomatics 1998; 39: 491-500.

5. Aw DC, Thong JY, Chan HL. Delusional parasitosis: case series of 8 patients and review of the literature. Ann Acad Med Singapore 2004; 33: 89-94.

6. Bhatia MS, Jagawat T, Choudhary S. Delusional parasitosis: a clinical profile. Int J Psychiatry Med 2000; 30: 83-91.

7. Adunsky A. Early post-stroke parasitic delusions. Age Ageing 1997; 26: 238-9.

8. Musso MW, Jones GN, Heck MC, Gouvier D. Delusional parasitosis as a presenting feature of HIV dementia: a case study. Appl Neuropsychol Adult 2013; 20: 66-72.

9. Steinert T, Studemund H. Acute delusional parasitosis under treatment with ciprofloxacin. Pharmacopsychiatry 2006; 39: 159-60.

10. Dunn J, Murphy MB, Fox KM. Diffuse pruritic lesions in a 37-year-old man after sleeping in an abandoned building. Am J Psychiatry 2007; 164: 1166-72.

11. Aleshire I. Delusion of parasitosis: report of successful care with antipellagrous treatment. J Am Med Assoc 1954; 155: 15-7.

12. Lee WR. Matchbox sign. Lancet 1983; 2: 457-8.

13. Szepietowski JC, Salomon J, Hrehorów E, et al. Delusional parasitosis in dermatological practice. J Eur Acad Dermatol Venereol 2007; 21: 462-5.

14. Zomer SF, De Wit RF, Van Bronswijk JE, et al. Delusions of parasitosis. A psychiatric disorder to be treated by dermatologists? An analysis of 33 patients. Br J Dermatol 1998; 138: 1030-2.

15. Freudenmann RW, Lepping P, Huber M, et al. Delusional infestation and the specimen sign: a European multicentre study in 148 consecutive cases. Br J Dermatol 2012; 167: 247-51. 
16. Jeon C, Nakamura M, Koo J. Examining specimens brought in by a patient with delusional parasitosis. I Am Acad Dermatol 2018; 78: e1.

17. Ladizinski B, Elpern DJ. Dermoscopy in delusions of parasitosis. Int J Dermatol 2013; 52: 838-9.

18. Jeon C, Nakamura M, Koo J. The demand for skin biopsy from a patient with delusional parasitosis. J Am Acad Dermatol 2017; 77: e125.

19. Guarneri F, Guarneri C, Mento G, Ioli A. Pseudo-delusory syndrome caused by Limothrips cerealium. Int I Dermatol 2006; 45: 197-9.

20.Chigusa Y, Shinonaga S, Koyama Y, et al. Suspected intestinal myiasis due to Dryomyza formosa in a Japanese schizophrenic patient with symptoms of delusional parasitosis. Med Vet Entomol 2000; 14: 453-7.

21. Hamann K, Avnstorp C. Delusions of infestation treated by pimozide: a double-blind crossover clinical study. Acta Derm Venereol 1982; 62: 55-8.

22. Lindskov R, Baadsgaard O. Delusions of infestation treated with pimozide: a follow-up study. Acta Derm Venereol 1985; 65: 267-70.

23. Elmer KB, George RM, Peterson K. Therapeutic update: use of risperidone for the treatment of monosymptomatic hypochondriacal psychosis. J Am Acad Dermatol 2000; 43: 683-6.

24.Sandoz A, LoPiccolo M, Kusnir D, Tausk FA. A clinical paradigm of delusions of parasitosis. J Am Acad Dermatol 2008; 59: 698-704.

25. Campbell EH, Elston DM, Hawthorne JD, Beckert DR. Diagnosis and management of delusional parasitosis. J Am Acad Dermatol 2019; 80: 1428-34.

26. Narumoto J, Ueda H, Tsuchida H, et al. Regional cerebral blood flow changes in a patient with delusional parasitosis before and after successful treatment with risperidone: a case report. Prog Neuropsychopharmacol Biol Psychiatry 2006; 30: 737-40.

27. Wooltorton E. Risperidone (Risperdal): increased rate of cerebrovascular events in dementia trials. CMAJ 2002; 167: 1269-70.

28. Brodaty H, Ames D, Snowdon J, et al. A randomized placebocontrolled trial of risperidone for the treatment of aggression, agitation, and psychosis of dementia. J Clin Psychiatry 2003; 64: 134-43.

29. Shin JY, Choi NK, Jung SY, et al. Risk of ischemic stroke with the use of risperidone, quetiapine and olanzapine in elderly patients: a population-based, case-crossover study. J Psychopharmacol 2013; 27: 638-44.

30. Shin JY, Choi NK, Lee J, et al. Risk of ischemic stroke associated with the use of antipsychotic drugs in elderly patients: a retrospective cohort study in Korea. PLoS One 2015; 10: e0119931.

31. Finkel S, Kozma C, Long S, et al. Risperidone treatment in elderly patients with dementia: relative risk of cerebrovascular events versus other antipsychotics. Int Psychogeriatr 2005; 17: 617-29.

32. Huang WL, Chang LR. Aripiprazole in the treatment of delusional parasitosis with ocular and dermatologic presentations. J Clin Psychopharmacol 2013; 33: 272-3.

33. Rocha FL, Hara C. Aripiprazole in delusional parasitosis: case report. Prog Neuropsychopharmacol Biol Psychiatry 2007; 31: 784-6.

34. Freudenmann RW, Schönfeldt-Lecuona C, Lepping P. Primary delusional parasitosis treated with olanzapine. Int Psychogeriatr 2007; 19: 1161-8.
35. Bosmans A, Verbanck P. Successful treatment of delusional disorder of the somatic type or "delusional parasitosis" with olanzapine. Pharmacopsychiatry 2008; 41: 121-2.

36. Freudenmann RW, Kühnlein P, Lepping P, Schönfeldt-Lecuona C. Secondary delusional parasitosis treated with paliperidone. Clin Exp Dermatol 2009; 34: 375-7.

37. Milia A, Mascia MG, Pilia G, et al. Efficacy and safety of quetiapine treatment for delusional parasitosis: experience in an elderly patient. Clin Neuropharmacol 2008; 31: 310-2.

38. Yorston G. Treatment of delusional parasitosis with sertindole. Int J Geriatr Psychiatry 1997; 12: 1127-8.

39. De Berardis D, Serroni N, Marini S, et al. Successful ziprasidone monotherapy in a case of delusional parasitosis: a one-year follow-up. Case Rep Psychiatry 2013; 2013 : 913248.

40.Monk BE, Rao YJ. Delusions of parasitosis with fatal outcome. Clin Exp Dermatol 1994; 19: 341-2.

41. Bourgeois ML, Duhamel P, Verdoux H. Delusional parasitosis: folie à deux and attempted murder of a family doctor. Br J Psychiatry 1992; 161: 709-11. 